911.3: $796.5(477)$

\author{
$\therefore$ \\ - опорницьк \\ ьвівський н ціон льний університет імені в н \\ вул. . орошенк , 41, м. ввів, 79000, кр їн
}

ем тично систем тизов но сукупність етнофестив лів ьвівської обл., розкрито просторовоч сові особливості орг ніз ції етнофестив льного туризму в регіоні. пропонов но конкретні рекоменд ції щодо перспективного розвитку етнофестив льного туризму в ьвівській обл.

лючові слов : етнічний туризм, етнофестив ль, етнофестив льний туризм, кл сифік ція фестив лів, геогр фія етнофестив лів.

днією з головних озн к суч сного культурного простору кр їни, і ьвівщини зокрем , є н дзвич йно швидке поширення фестив льного руху, що, почин ючи з 1990-х років, охопив пр ктично всі міст й н віть сел . ричин ми, що спровокув ли фестив льний “бум”, ст ло пр гнення розкрити етнокультурні здобутки т ширше презентув ти мистецьку сп дщину кр їни.

н чення фестив льних дійств у структурі туризму недооцінене т м йже цілком перебув є поз ув гою укр їнської н уки. н ліз н укових пр ць, присвячених предмету вивчення, свідчить, що досі нем об’єктивного комплексного дослідження, у якому було б розглянуто суч сні фестив лі н ьвівщині як цілісну систему.

кту льність н шого дослідження поляг є у вивченні фестив лів у ьвівській обл. як цілісного суспільного явищ, виявленні зн чення і впливу конкретних кцій н ст н повсякденного життя. ур хув нням кту льності досліджув ної проблеми, незн чної кількості досліджень з цієї тем тики, т кож з огляду н об'єктивну потребу у вивченні суч сного укр їнського фестив льного процесу визн чено вибір теми дослідження.

еоретичну 6 зу дослідження фестив льного туризму ст новлять пр ці з проблем формулюв ння термінології, структури т функцій фестив льного процесу . вед , бкін , специфічних рис культурно-пізн в льного і подієвого туризму кр їни . юбіцевої, . ейдик , . льської, . утинського. н ліз суч сного музичного фестив льного процесу в кр їні викон но в дослідженнях · ьячкової, . інькевич, . ияновської, . р вцової, . вед т ін. [1, 2, 4-6, 8-13].

естив ль (фр нц. festival, від л т. festivus - святковий) - це м сове святкув ння, пок з чи огляд досягнень музичного, те тр льного, естр дного, циркового бо кіномистецтв . ля туризму й плек ння н ціон льної культури особливе зн чення м ють етнофестив лі.

тнофестив лі-це фестив лі, що презентують фольклорне б г тство, побут $\mathrm{m}$ звич ї, культурні цінності, духовну й м тері льну сп дщинун роду бо етнічної групи.

(C) опорницьк ., 2012 
родження і розвиток міжн родного фестив льного руху в кр їні ст ли можливими лише зі здобуттям держ вної нез лежності.

естив льний рух є пок зником і своєрідним к т ліз тором інтенсивності т якості мистецького життя будь-якої кр їни. естив лі, як переконує світовий і укр їнський досвід, це своєрідні осередки, що визн ч ють н прями розвитку мистецтв , формують нові ідеї, відкрив ють нові обрії творчої діяльності [13].

ропонуємо систем тизов ний 3 ч совим критерієм перелік н йпопулярніших етнофестив лів ьвівщини. г то з них прив блює тим, що не потребує б г то ч су бо коштів для відвід ння, проте г р нтує м су вр жень т емоцій н зг дку.

блиця 1

\begin{tabular}{|c|c|c|c|c|c|}
\hline № & 3В & рофіль & $\begin{array}{c}\text { ісце } \\
\text { проведення }\end{array}$ & $\begin{array}{l}\text { ількість } \\
\text { днів }\end{array}$ & $\begin{array}{c}\text { ік } \\
3 \text { снув ння } \\
\end{array}$ \\
\hline 1 & вято шокол ду & $\begin{array}{l}\text { строномія й } \\
\text { г лицьк міськ } \\
\text { етнокультурн } \\
\text { сп дщин } \\
\end{array}$ & ьвів & 2 & 2008 \\
\hline 2 & $\begin{array}{l}\text { естини } \\
\text { “ елик г ївк ” }\end{array}$ & $\begin{array}{c}\text { ольклорно- } \\
\text { мистецький }\end{array}$ & ьвів & 3 & \\
\hline 3 & $\begin{array}{l}\text { іжн родний фестив ль } \\
\text { лемківської пис нкки }\end{array}$ & тномистецький & ьвів & 2 & 2010 \\
\hline 4 & $\begin{array}{l}\text { іське свято } \\
\text { “ ень тяр " }\end{array}$ & $\begin{array}{l}\text { истецький } \\
\text { (г лицьк міськ } \\
\text { етнокультурн } \\
\text { сп дщин ) }\end{array}$ & ьвів & 1 & 2008 \\
\hline 5 & $\begin{array}{l}\text { іжн родний етнодж - } \\
\text { зовий фестив ль } \\
\text { “ люгери ьвов ” }\end{array}$ & тномузичний & ьвів & 4 & 2003 \\
\hline 6 & $\begin{array}{l}\text { іжн родний фести-в ль } \\
\text { “ колі друзів” }\end{array}$ & тномистецький & ьвів & 5 & 2006 \\
\hline 7 & $\begin{array}{l}\text { тнофестив ль “ ьвів - } \\
\text { столиця ремесел” }\end{array}$ & тнокультурний & ьвів & 3 & $\begin{array}{l}2008, \text { тричі } \\
\text { в рік }\end{array}$ \\
\hline 8 & ень міст & тнокультурний & ьвів & 3 & 2008 \\
\hline 9 & $\begin{array}{ll}\text { ень } & \text { тері } \\
\end{array}$ & тнокультурний & ьвів & 1 & 2008 \\
\hline 10 & $\begin{array}{l}\text { оровий фестив ль } \\
\text { “ півоче поле” }\end{array}$ & ольклорний & ьвів & 1 & 2006 \\
\hline 11 & $\begin{array}{l}\text { іжн родний фести-в ль } \\
\text { руно ульц }\end{array}$ & тномистецький & рогобич & 6 & 2007 \\
\hline 12 & $\begin{array}{c}\text { олодіжний фестив ль- } \\
\text { конкурс “ } \\
\text { евченко - }\end{array}$ & тнокультурний & ьвів & 2 & 2008 \\
\hline 13 & \begin{tabular}{l}
\multicolumn{2}{c}{ естив ль-конкурс } \\
“ жерел оршин, \\
\end{tabular} & тномистецький & оршин & 2 & 2007 \\
\hline 14 & $\begin{array}{l}\text { естив ль середньо-вічної } \\
\text { культури “ ьвів } \\
\text { ст род вній”” }\end{array}$ & тнокультурний & ьвів & 2 & 2009 \\
\hline 15 & $\begin{array}{l}\text { іжн родний } \\
\text { туристичний фестив ль } \\
\text { “ вейк фест личин ”, }\end{array}$ & $\begin{array}{l}\text { портивно- } \\
\text { туристичний, } \\
\text { етноярм рковий }\end{array}$ & $\begin{array}{l}\text { кр їн, } \\
\text { ольщ, } \\
\text { лов ччин , } \\
\text { ехія, } \\
\text { горщин }\end{array}$ & 7 & 2006 \\
\hline
\end{tabular}


ісля холодної зими людям хочеться сонця і тепл , вибр тися з приміщень і весело проводити ч с із друзями. ку змогу їм н д ють н йрізном нітніші етнофестив лі і святкові дійств весняно-літньої пори. продовж весни у ьвівській обл. проводять пон д 20 фестив лів різном нітної тем тики, т к що кожен охочий може зн йти щось для душі (т бл. 1). скільки погод н весні ще не д є змоги орг нізовув ти етнофестив лі десь н природі, тому всі вони відбув ються у міст х, більшість в обл сному центрі ьвові. оч позитивною тенденцією є те, що зн чну ч стину все ж т ки проводять повністю бо ч стково н відкритих м йд нчик х (“ вято окол ду”, “ люгери ьвов ”, “ т ре місто”, “ ьвів - столиця ремесел”, “ еликодні г ївки”, “ ень тяр ”т ін.).

жливим у пл ні розвитку міжн родного туризму є проведення фестив лю “ вейк фест личин ", який з луч є не тільки молодь ьвівської обл., й гостей з чотирьох сусідніх кр їн - ольщі, лов ччини, ехії й горщини. ктивні уч сники цього фестив лю н велосипед х відвідують місця, у яких з вдяки творчому генію письменник росл в шек “побув в” цей просл влений літер турний герой.

ксим льно н сичен різнопл новими етнофестив лями і святковими дійств ми, розр хов ними н численних туристів, літня пор . цей ч с ьвівську обл. для уч сті у фестив лях, 3 підр хунк ми експертів, відвідує 0,7-1,5 млн туристів з інших регіонів кр їни т з-з кордону.

іто у всіх львів'ян і туристів соціюється з відпустк ми і відпочинком. сім, хто 6 ж є провести цю пору ктивно й весело, з духом свободи у колі друзів, у ьвівській обл. пропонують близько трьох десятків різнопл нових етнофестив льних дійств з н йрізном нітнішими прогр м ми (т бл. 2).

ільшість етнофестив лів у цю пору перебир ються н природу под льше від міської суєти (фестив лі у шкові, ідк мені, л вському, венигороді). прикл д, 19 з 35 фестив лів проводять не у ьвові, що є хорошим пок зником для розвитку фестив льного туризму у регіоні. дже той ф кт, що фестив льні дійств проводять у м льовничих туристичних місцевостях, не у великому шумному місті, збільшує кількість тих, хто $б$ ж є відвід ти подібні з ходи.

тже, влітку $54 \%$ етнофестив лів ьвівщини сприяють промоції с ме ьвівського регіону, збільшують кількість м ндрівників у м лі туристичні центри т рекре ційні місцевості регіону.

оряд $з$ суто етнофестив лями (фольклорно-етногр фічного профілю) влітку н ьвівщині проводять і музичні, і кінофестив лі, і мистецькі, і н віть екологічні фестив лі (н прикл д, “ исті джерел угу”), т к що кожен турист і поціновув ч укр їнської культури зн йде свій фестив ль, який принесе йому м су позитивних емоцій.

ісля н сиченого фестив льного літ н осіннє міжсезоння прип д є певне 3 тишшя. н ст нням осені простежується суттєвий сп д фестив льного руху. е пояснюють т кими чинник ми: по-перше, зміною погоди - ст є холодно, почин ються дощі; по-друге, н йбільшою групою відвідув чів фестив лів є молодь - учні й студенти, з поч тком осені в них почин ється новий н вч льний рік і не всі можуть вирв тись; і по-третє, осінь - це сезон польових робіт.

ількість щорічних етнофестив лів ьвівської обл. цієї пори не перевищує одного десятк (т бл. 3). уристично н йм совішими з-поміж них є фестив лі історичної реконструкції середньовічної історії т коз цької культури.

сінні фестив лі ввівщини м ють міжн родне зн чення і передб ч ють не тільки розв ги, й конкурсну прогр му для уч сників. прикл д, фестив ль “ олотий ев” $є$ членом вропейського те тр льного форуму (IETM) і соці ції міжн родних фестив - 
опорницьк

блиця 2

ітні етнофестив лі ьвівської обл.

\begin{tabular}{|c|c|c|c|c|c|}
\hline № & 3в & рофіль & $\begin{array}{c}\text { ісце } \\
\text { проведення }\end{array}$ & $\begin{array}{r}\text { іль- } \\
\text { кість } \\
\text { днів } \\
\end{array}$ & $\begin{array}{l}\text { ік } \\
3 \text { сну- } \\
\text { в } \text { Ння } \\
\end{array}$ \\
\hline 1 & $\begin{array}{l}\text { іжн родний фестив ль ди- } \\
\text { тячої творчості “ } \\
\text { пі т л нти } \\
\text { під покровом короля }\end{array}$ & $\begin{array}{r}\text { Удожньо- } \\
\text { мистецький }\end{array}$ & ьвів & 2 & 2010 \\
\hline 2 & $\begin{array}{l}\text { е тр льний дитячий } \\
\text { фестив ль “" } 3 \text { К у г ю” } \\
\end{array}$ & $\begin{array}{r}\text { е тр льний, } \\
\text { фольклорний }\end{array}$ & ьвів & 2 & 2003 \\
\hline 3 & естив ль у шкові & $\begin{array}{l}\text { тнокультурний, } \\
\text { музичний }\end{array}$ & $\begin{array}{l}\text { с. шків, } \\
\text { овківський p-н }\end{array}$ & 2 & 2007 \\
\hline 4 & $\begin{array}{l}\text { истецький фестив ль “ іто } \\
\text { н ринку” }\end{array}$ & истецький & ьвів & 23 & 2008 \\
\hline 5 & естив ль пив “ убок ев ” & $\begin{array}{r}\text { строномічний, } \\
\text { етноярм рковий }\end{array}$ & ьвів & 2 & 1999 \\
\hline 6 & $\begin{array}{l}\text { сеукр їнський фестив ль } \\
\text { укр їнської пісні “ } \text { віт п пороті” }\end{array}$ & тномузичний & трий & 3 & 1993 \\
\hline 7 & $\begin{array}{l}\text { іжн родний етнічний } \\
\text { фестив ль “ }{ }^{\text {p їн }} \text { рій” } \\
\end{array}$ & тнічний & ьвів & 1 & 2008 \\
\hline 8 & іжн родний “ лезмер ест” & истецький & ьвів & 3 & 2009 \\
\hline 9 & вято сиру і вин & $\begin{array}{r}\text { строномічний, } \\
\text { етноярм рковий }\end{array}$ & ьвів & 1 & 2010 \\
\hline 10 & “ естини і ни” & истецький & ьвів & 1 & 2010 \\
\hline 11 & $\begin{array}{l}\text { іжн родний фестив ль “Fort. } \\
\text { missia”" }\end{array}$ & $\begin{array}{l}\text { истецький, } \\
\text { музичний }\end{array}$ & $\begin{array}{l}\text { c. оповичі, } \\
\text { прикордоння }\end{array}$ & 3 & 2009 \\
\hline 12 & сесвітні ойківські фестини & тнокультурний & M. ypк & 3 & 1992 \\
\hline 13 & $\begin{array}{l}\text { іжн родний фольклорний } \\
\text { фестив ль “" тновир” }\end{array}$ & $\begin{array}{c}\text { ольклорно- } \\
\text { етногр фічний }\end{array}$ & ьвів & 5 & 2007 \\
\hline 14 & вято ліб & $\begin{array}{r}\text { строномічний, } \\
\text { етноярм рковий }\end{array}$ & ьвів & 1 & 2005 \\
\hline 15 & $\begin{array}{c}\text { іжн родний музичний } \\
\text { фестив ль “ } \text { л вське-рок” }\end{array}$ & $\begin{array}{c}\text { узичний, } \\
\text { етнокультурний }\end{array}$ & $\begin{array}{l}\text { с. л вське, } \\
\text { колівський р-н }\end{array}$ & 3 & 2007 \\
\hline 16 & тнофестив ль “ ідк мінь” & тномузичний & $\begin{array}{l}\text { с. ідк мінь, } \\
\text { родівський p-н }\end{array}$ & 3 & 2007 \\
\hline 17 & $\begin{array}{l}\text { тнофестив ль “уд - родове } \\
\text { містечко иговських” }\end{array}$ & $\begin{array}{l}\text { тнокультурний, } \\
\text { коз цький }\end{array}$ & $\begin{array}{l}\text { c. уд , ид - } \\
\text { чівський р-Н }\end{array}$ & 2 & 2008 \\
\hline 18 & тнофестив ль “ венигород” & тнокультурний & $\begin{array}{l}\text { c. венигород, } \\
\text { устомитівський } \\
\text { p-н }\end{array}$ & 2 & 2010 \\
\hline 19 & $\begin{array}{l}\text { тнофестив ль “ исті джерел } \\
\text { угу” }\end{array}$ & $\begin{array}{l}\text { тноекологічний, } \\
\text { фольклорно- } \\
\text { етногр фічний }\end{array}$ & $\begin{array}{l}\text { с. ерхобуж, } \\
\text { олочівський p-н }\end{array}$ & 3 & 2008 \\
\hline 20 & $\begin{array}{l}\text { истецький фестив ль ре- } \\
\text { гіон льної культури } \\
\text { “ рп тія” }\end{array}$ & тнічний & $\begin{array}{l}\text { с. врів, т ро- } \\
\text { с мбірський р-н }\end{array}$ & 2 & 2009 \\
\hline 21 & естив ль “" хід” & тномузичний & c. венигород & 2 & 2009 \\
\hline 22 & естив ль духових оркестрів & узичний & ьвів & 2 & 2010 \\
\hline 23 & $\begin{array}{l}\text { іжн родний фестив ль } \\
\text { “ ордон” }\end{array}$ & $\begin{array}{c}\text { узичний, } \\
\text { етноярм рковий }\end{array}$ & $\begin{array}{l}\text { с. гринів, о- } \\
\text { к льський р-н }\end{array}$ & 3 & 2008 \\
\hline 24 & $\begin{array}{l}\text { тнофестив ль “ ульчиці- } \\
\text { фест” }\end{array}$ & $\begin{array}{l}\text { тнокультурний, } \\
\text { кОз цьКий }\end{array}$ & $\begin{array}{l}\text { с. ульчиці, - } \\
\text { мбірський р-н }\end{array}$ & 2 & 2009 \\
\hline
\end{tabular}


в лів (IFEA), з вдяки “ онтр ст м” ьвів є в жливим центром музичного мистецтв у хідній вропі, міжн родними є т кож те тр льний фестив ль “ $р$ бин ” і кінофестив ль “ римб”.

блиця 3

\begin{tabular}{|c|c|c|c|c|c|}
\hline № & зв & рофіль & $\begin{array}{c}\text { ісце } \\
\text { проведення }\end{array}$ & $\begin{array}{r}\text { іль- } \\
\text { кість } \\
\text { днів } \\
\end{array}$ & $\begin{array}{lc}\text { ік } \\
3 \text { сну- } \\
\text { В } & \text { нНя } \\
\end{array}$ \\
\hline 1 & $\begin{array}{l}\text { іське свято “ } \\
\text { ьвов }\end{array}$ & $\begin{array}{l}\text { строномічний, } \\
\text { етноярм рковий }\end{array}$ & ьвів & 2 & 2007 \\
\hline 2 & $\begin{array}{l}\text { естив ль втентичного } \\
\text { мистецтв “" еретено” }\end{array}$ & тнічний & ьвів & 1 & 2010 \\
\hline 3 & $\begin{array}{l}\text { естив ль д вньоруської } \\
\text { культури “" уст нь” }\end{array}$ & $\begin{array}{l}\text { сторичної } \\
\text { реконструкції, етнічний }\end{array}$ & $\begin{array}{l}\text { с. рич, } \\
\text { колівський p-н }\end{array}$ & 3 & 2006 \\
\hline 4 & $\begin{array}{l}\text { естив ль-конкурс } \\
\text { мистецтв “" ришт левий } \\
\text { руск вець” }\end{array}$ & истецький & м. руск вець & 2 & 2005 \\
\hline 5 & $\begin{array}{l}\text { іжн родний } \\
\text { те тр льний фестив ль } \\
\text { “ олотий ев” }\end{array}$ & $\begin{array}{l}\text { е тр льний, д вньої } \\
\text { міської культури }\end{array}$ & ьвів & 10 & 1992 \\
\hline 6 & $\begin{array}{l}\text { естив ль “" яльковий } \\
\text { світ” }\end{array}$ & $\begin{array}{l}\text { истецький, д вньої } \\
\text { міської культури }\end{array}$ & ьвів & 10 & 2009 \\
\hline 7 & $\begin{array}{c}\text { естив ль родинної } \\
\text { творчості “ ерегиня” }\end{array}$ & истецький & ьвів & 1 & 2006 \\
\hline 8 & $\begin{array}{l}\text { естив ль Д вньої } \\
\text { музики у ьвові }\end{array}$ & $\begin{array}{l}\text { узичний, д вньої } \\
\text { міської культури }\end{array}$ & ьвів & 10 & 2002 \\
\hline 9 & $\begin{array}{c}\text { естив ль ков льського } \\
\text { мистецтв “" }{ }^{\text {лiзний }} \text { ев” }\end{array}$ & $\begin{array}{l}\text { тномистецький, } \\
\text { етноярм рковий }\end{array}$ & ьвів & 3 & 2006 \\
\hline
\end{tabular}

блиця 4

имові етнофестив лі і святкові дійств ьвівської обл.

\begin{tabular}{|c|c|c|c|c|c|}
\hline № & 3в & рофіль & $\begin{array}{c}\text { ісце } \\
\text { проведення }\end{array}$ & $\begin{array}{l}\text { ількість } \\
\text { днів }\end{array}$ & $\begin{array}{c}\text { iк } \\
3 \text { снув ння }\end{array}$ \\
\hline 1 & $\begin{array}{l}\text { іжн родний етнодж зовий } \\
\text { фестив ль “Jazz Bez" }\end{array}$ & узичний & ьвів & 10 & 2000 \\
\hline 2 & вято святого $\quad$ икол я & $\begin{array}{l}\text { елігійно- } \\
\text { етнокультурний }\end{array}$ & ьвів & 1 & 2009 \\
\hline 3 & $\begin{array}{l}\text { естив ль “ п л х іздвяної } \\
\text { звізди” }\end{array}$ & $\begin{array}{c}\text { елігійно- } \\
\text { мистецький }\end{array}$ & ьвів & 2 & 2007 \\
\hline 4 & $\begin{array}{l}\text { іздвяний фестив ль “ елик } \\
\text { коляд ", }\end{array}$ & $\begin{array}{l}\text { елігійно- } \\
\text { етнокультурний }\end{array}$ & ьвів & 24 & 2000 \\
\hline 5 & вято мпух & строномічний & ьвів & 3 & 2008 \\
\hline
\end{tabular}

им 3 н родним к ленд рем - пор свят іздвяного циклу. ме тому зн чн кількість етнофестив льних дійств пов'яз н 3 ними. ьвівській обл. в зимовий період щороку відбув ється близько десяти фестив лів і м сових святкових дійств (т бл. 4). звич й, вони приурочені до святкув нь н ціон льних релігійних свят і уже в н зв х 
відобр ж ють прит м нну тому чи іншому святу етно трибутику (“ п л х іздвяної звізди”, “ вято мпух ”). стин зимових дійств - це хореогр фічно-фольклорні конкурси.

одо тем тики зимових етнофестив лів, то вон не відст є від літньої. ут є тетр льні й кінофестив лі, музичні й мистецькі, культурні й г строномічні.

тже, н ьвівщині є більше півсотні різном нітних м сових з ходів і святкув нь, що цілком підп д ють під к тегорію “етнофестив ль”. роте більшість етнофестив лів відбув ється в обл сному центрі - ьвові, с ме: $68 \%$ усіх етнофестив лів регіону. ю тенденцію можн пояснити б г тьм чинник ми, зокрем : ліпш інфр структур , більше можливостей для з лучення спонсорів, більше туристів тощо.

нш тенденція, яку можн виявити з т блиць, поляг є в тому, що зн чн кількість етнофестив лів прип д є н весну і літо, с ме: 31 і $40 \%$, відповідно. имовий період не м є попиту серед орг ніз торів різном нітних дійств, ун слідок чого н зиму прип д є лише $14 \%$. е можн пояснити тим, що етнофестив ль - це здебільшого т. зв. «open-air» дійство, і орг нізовув ти його з темпер тури нижчої від $-10--20^{\circ}$ iз снігоп дом не доцільно.

ідобр зимо структуру етнофестив лів ьвівської обл. $з$ пор ми року у вигляді дігр ми (рис. 1).
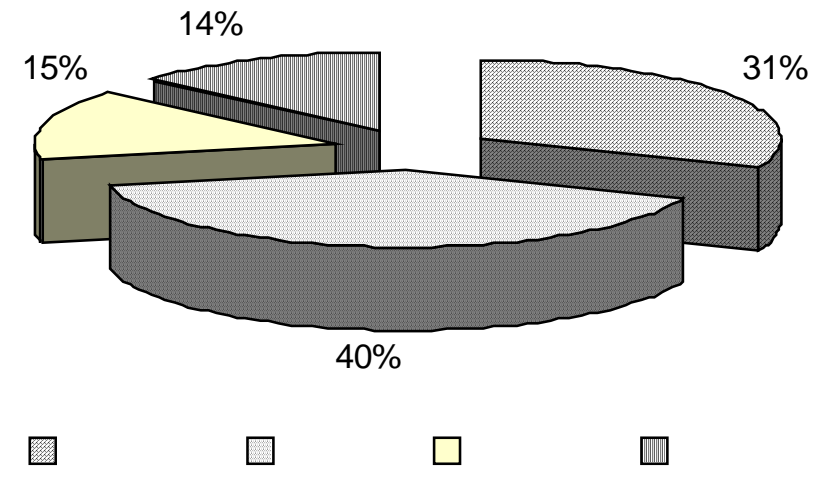

ис. 1. труктур етнофестив лів з пор ми року.

рив лість етнофестив лів - від одного дня до одного місяця. роте н йпопулярнішими є “дійств вихідного дня" - дв -три дні. им ч совим х р ктеристик м відповід є $41 \%$ усіх етнофестив лів. дже т кий термін н йліпше прив блює туристів, якщо н етнофестив ль орг ніз тори відводять менше ч су, то турист м звідд ля не хочеться їх ти, якщо більше, то вони не встиг ють через 3 йнятість н роботі. рив лість етнофестив лів ьвівської обл. ми простежили з допомогою ді гр ми (рис. 2).

одо ч сових х р ктеристик етнофестив лів ьвівщини, то простежується тенденція, що з кожним роком кількість фестив лів довгожителів зрост є. ожемо стверджув ти, що близько $26 \%$ етнофестив лів ьвівщини змогли подол ти п’ятирічний 6 p'єр. кож з кожним роком з'являються нові етнофестив лі, і тільки з вдяки вд лій орг ніз ції вони зможуть жити д лі. дже, як свідчить досвід 2010 р., в орг ніз торів фестив лів є ще н д чим пр цюв ти. прикл д, можн н вести фестив ль культур н родів світу “ вірж”, який з великим ск нд лом з зн в фі ско і попсув в репут цію фестив лям ьвівщини. 


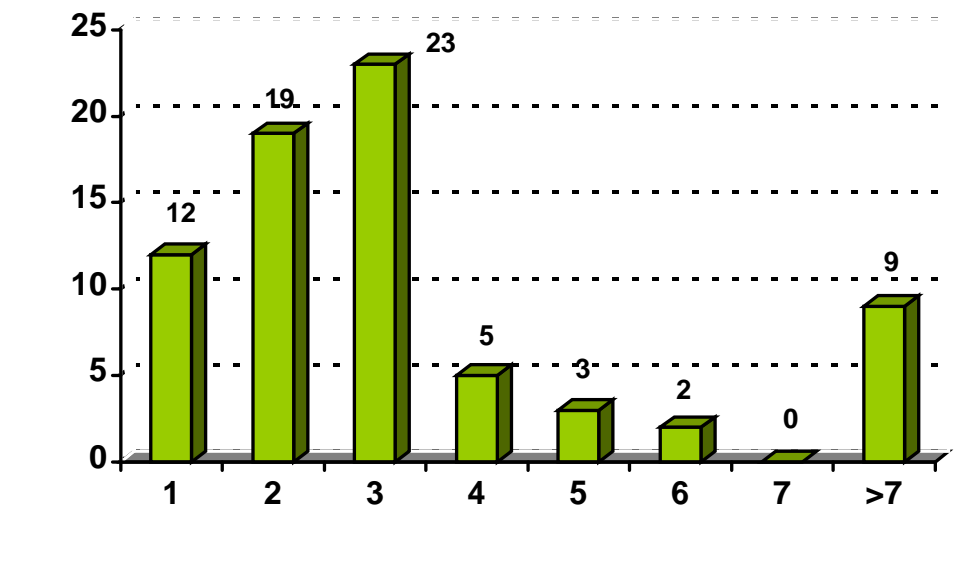

ис. 2. піввідношення між кількістю т трив лістю етнофестив лів, дні.

гідно з опитув ннями львівських с йтів, н йпопулярнішими є: серед міських “ вято шокол ду”, “ вято к ви” і “Jazz Bezz” (22, 15, 15 \%, відповідно), серед поз міських - “ ідк мінь” [4].

к 6 чимо з т бл. 1-4, ьвівськ обл. може пиш тися етнофестив льним рухом. еред обл стей-сусідів з різном ніттям і кількістю ьвівщин конкурує із к рп тською т в но- р нківською обл стями, в яких т кож упродовж року відбув ється пон д сто популярних серед туристів етнофестив лів регіон льного, всеукр їнського й міжн родного м сшт бів.

тже, перші фестив лі ьвівщини виникли як урочисті ходи, кортежі, пізніше ст ли м совими видовищ ми, пов'яз ними з певними подіями в культурному т соці льному житті суспільств , д лі з'явилися міжн родні фестив лі, які ст ли передумовою виникнення фестив льного туризму.

ьогодні нез перечно те, що міжн родні етнофестив лі в кр їні відігр ють суттєву роль у вітчизняній культурі, сприяють ктивіз ції мистецького життя н шої держ ви.

ме вони є н йв жливішими чинник ми утвердження кр їни в світі як держ ви 3 високорозвиненою культурою, тр диційним і суч сним мистецтвом. роки нез лежності ці етнофестив лі ст ли візитними к ртк ми н шої кр їни у світі і суттєвим чинником з лучення потоків іноземних туристів.

одо чинників розвитку етнофестив льного туризму, то можемо виділити т кі головні:

- здобуття нез лежності, свободи діяльності;

- проп г нд міжн родної дружби і співпр ці, культурного обміну;

- зб г чення т розвиток мистецтв , б ж ння демонструв ти його широким верств м суспільств ;

- відновлення тр дицій і пл сту етнокультурної сп дщини;

- розширення культури і світогляду людей;

- зрост ння витр т н туристичні подорожі (фестив льний туризм є досить дешевим, і тому його популярність серед укр їнців з кожним роком зрост $є)$ ). 
1. бкин . . пеци льные виды туризм : учеб. пособие / . . бкин. остов-н-. . : еникс, 2008. $-252 \mathrm{c}$

2. ейдик . . екре ційно-туристичні ресурси кр їни : моногр фія / . . ейдик. . : льтерпрес, 2002. 320 с.

3. отельне господ рство т туризм у ьвівській обл сті (з 2009 рік) : ст тист. зб. ьвів, $2010 .-88$ с. 4. $p$ вцов . несок міжн родних фестив лів у зб г чення т розвиток укр їнського мистецтв . - ежим доступу: http://who-is-who.com.ua

5. юбіцев . . инок туристичних послуг : н вч. посібник / . . юбіцев . . : льтерпрес, 2002. $-436 \mathrm{c}$.

6. льськ . . уризм у міжн родному і н ціон льному вимір х. сторія і суч сність : моногр фія / . . льськ , . . утинський, . . ньків. - ьвів: 2008. -268 c.

7. цол .. екре ційно-туристичний комплекс кр їни : моногр фія / . . цол . - ьвів : н-т регіон льних досліджень , 1997. - 259 с.

8. утинський . . еогр фія туризму кр їни : н вч.-метод. посібник / . . утинський. - . : ентр н вч. літер тури, 2004. - 160 с.

9. утинський . . уристичний комплекс рп тського регіону кр їни : моногр фія / . . утинський, . . тецюк. ернівці : ниги - , 2008. - 440 с.

10. утинський . . тнофестив льний туризм: теоретичні з с ди й етногеогр фічні спекти орг ніз ції / . . утинський, . . опорницьк // еогр фія т туризм : н ук. зб.; відп. ред. . . лійник. - ., 2011. - ип. 14. - . 129-135.

11. молій . . нциклопедичний словник довідник з туризму / . . молій, . . едорченко, . . ибух. . : лово, 2006. -372 с.

12. окол . . снови туризмозн вств : н вч. посібник / . . окол. - . : йн, 1999. -277 с.

13. вед . . енденції розвитку міжн родних фестив лів суч сної музики в кр їні н новому ет пі (1990-2005 рр.) : втореф. дис... к нд. мистецтвозн вств : 17.00.01 / ьвівськ держ. музичн к демія ім. . . исенк / . . вед. - ьвів, 2006. -20 с.

m ття: н дійшл до редколегї̈ 06.10.2011 прийнят до друку 20.11.2011

\section{ETHNOFESTIVAL TOURISM IN THE LVIV REGION: THEMATIC STRUCTURE AND SPATIAL-TEMPORAL CHARACTERISTICS OF THE ORGANIZATION}

\section{Topornycka}

Ivan Franko National University of Lviv, . Doroshenko St., 41, UA - 79000 Lviv, Ukraine

The ethnofestivals in the Lviv Region have been systematized on the thematic approach. The spatial-temporal characteristics of the ethnofestival tourism in the region have been descibed. The specific recommendations for future development and promoting of festival tourism in Lviv Region have been proposed.

Key words: ethnic tourism, ethnofestival, ethnofestival tourism, festivals classification, geography of ethnofestival tourism. 


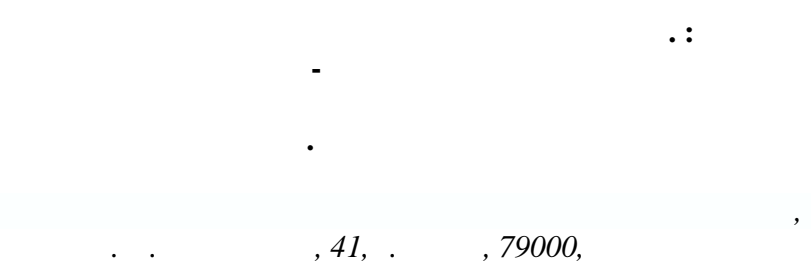

ем тически систем тизиров но совокупность этнофестив лей ьвовской обл., р скрыто простр нственно-временные особенности орг низ ции етнофестив льного туризм в регионе. редложено конкретные рекоменд ции по перспективному р звитию етнофестив льного туризм во ьвовской обл.

лючевые слов : этнический туризм, этнофестив ль, етнофестив льний туризм, кл ссифик ция фестив лей, геогр фия этнофестив лей. 